\title{
Skeletal Muscle Glycolysis, Oxidation, and Storage of an Oral Glucose Load
}

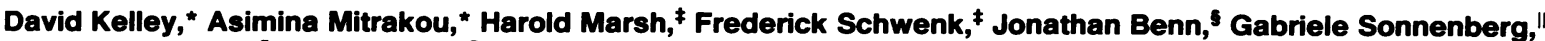 \\ Michael Arcangeli,' Thomas Aoki,' John Sorensen, ${ }^{\star *}$ Michael Berger," Peter Sonksen, ${ }^{5}$ and John Gerich* \\ *Diabetes Section, Division of Endocrinology and Metabolism, Departments of Medicine and Physiology, University of Pittsburgh \\ School of Medicine, Pittsburgh, Pennsylvania 15261; ${ }^{\ddagger}$ Endocrine Research Unit, Departments of Pediatrics and Anesthesiology, \\ Mayo Medical School, Rochester, Minnesota 55905; \$Department of Medicine, United Medical and Dental Schools of Guys \\ and St. Thomas Hospitals (St. Thomas Campus), London, United Kingdom SE1 7EH; "Department of Nutrition and Metabolic \\ Diseases, University of Dusseldorf, Dusseldorf, Federal Republic of Germany; 'Division of Endocrinology, Department \\ of Internal Medicine, University of California, Davis, Sacramento, California 95817; and **American Technology \\ and Ventures, Division of Baxter Travenol, Irvine, California 92664
}

\begin{abstract}
Although muscle is considered to be the most important site for postprandial glucose disposal, the metabolic fate of oral glucose taken up by muscle remains unclear. We, therefore, employed the dual isotope technique (intravenous, $\left[6-{ }^{3} \mathrm{H}\right]-$ glucose; oral, $\left.\left[1-{ }^{14} \mathrm{C}\right] \mathrm{glucose}\right)$, indirect calorimetry, and forearm balance measurements of glucose, lactate, alanine, pyruvate, $\mathrm{O}_{2}$, and $\mathrm{CO}_{2}$ in nine normal volunteers to determine the relative importance of muscle glycogenic, glycolytic, and oxidative pathways in disposal of an oral glucose load. During the $5 \mathrm{~h}$ after glucose ingestion $(1 \mathrm{~g} / \mathrm{kg}), 37 \pm 3 \%(24.9 \pm 2.3 \mathrm{~g})$ of the load was oxidized and $63 \pm 3 \%(42.8 \pm 2.7 \mathrm{~g})$ was stored. At least $29 \%(19.4 \pm 1.3 \mathrm{~g})$ was taken up by splanchnic tissues. Muscle took up $26 \%(17.9 \pm 2.9 \mathrm{~g})$ of the oral glucose coincident with a $50 \%$ reduction in its oxidation of fat. $15 \%$ of the oral glucose taken up by muscle $(2.5 \pm 0.9 \mathrm{~g})$ was released as lactate, alanine, or pyruvate; $50 \%(8.9 \pm 1.4 \mathrm{~g})$ was oxidized, and $35 \%$ $(6.4 \pm 2.3 \mathrm{~g})$ was available for storage. We conclude that muscle and splanchnic tissues take up a comparable percentage of an oral glucose load and that oxidation is the predominant fate of glucose taken up by muscle, with storage in muscle accounting for $<10 \%$ of the oral load. Thus, contrary to the prevailing view, muscle is neither the major site of storage nor the predominant site of disposal of an oral glucose load.
\end{abstract}

\section{Introduction}

Muscle is generally considered to be the predominant tissue responsible for insulin-mediated glucose disposal in normal man $(1,2)$ and the major site of insulin resistance in patients with noninsulin-dependent diabetes mellitus $(1,3)$. In the postabsorptive state, most glucose uptake occurs in noninsulin-sensitive tissues (4). It is, therefore, primarily in the postprandial state that insulin-stimulated muscle glucose uptake would be physiologically most important (5). Despite this role for muscle in postprandial glucose homeostasis, the metabolic fate of oral glucose taken up by muscle is unclear.

Address correspondence and reprint requests to Dr. Gerich, Clinical Research Center, 3488 Presbyterian-University Hospital, 230 Lothrop St., Pittsburgh, PA 15261.

Received for publication 17 August 1987 and in revised form 10 November 1987.

J. Clin. Invest.

(c) The American Society for Clinical Investigation, Inc. 0021-9738/88/05/1563/09 \$2.00

Volume 81, May 1988, 1563-1571
Theoretically, disposal of glucose by muscle should primarily involve storage as glycogen for subsequent use and glycolysis followed by either oxidation or release of potential gluconeogenic precursors such as lactate, alanine, and pyruvate. The latter pathway is of particular interest, since recent studies suggest that hepatic glycogen formation may occur primarily via glucose-6-phosphate derived from gluconeogenic precursors (indirect pathway) rather than glucose-6-phosphate derived from direct phosphorylation of glucose (6).

Experiments employing the hyperinsulinemic euglycemic clamp technique in conjunction with whole body indirect calorimetry indicate that most of the infused glucose undergoes nonoxidative disposal (glycogen formation and glycolysis) in muscle (7-9). These results, if applicable to the postprandial state, suggest that nonoxidative disposal in muscle may be the major fate of ingested glucose. Since balance studies across the human forearm (10-12) indicate that there is little net release of glycolytic intermediates after glucose ingestion, it would appear that, if nonoxidative disposal were the major fate of oral glucose, most of the glucose taken up by muscle should be stored as glycogen.

Such a conclusion, however, remains to be established and may be questioned on several grounds; first of all, in the only study to date directly examining this point, Nuttall et al. (13) found no increase in muscle glycogen after an oral glucose load in normal volunteers. Secondly, in euglycemic clamp experiments during which glucose disposal and plasma insulin concentrations exceeded those observed after oral glucose, Mott et al. (14) also failed to observe an increase of muscle glycogen. Conceivably, the inability to detect small changes in muscle glycogen content might explain these observations.

However, the proposal that muscle glycogen formation is the major fate of ingested glucose may also be questioned from a physiologic point of view. The classic studies of Andres et al. (15) indicate that during an overnight fast, muscle consumes at most only $\sim 10 \mathrm{~g}$ of its glycogen. If this deficit were completely replenished, it would account for only $10-15 \%$ of a conventional oral glucose load. On the other hand, energetic considerations suggest that oxidation may be the major fate of ingested glucose in muscle. In the postabsorptive state, fat is the predominant fuel in muscle (15). Previous studies employing indirect calorimetry have found that after glucose ingestion there is a $20-30 \%$ suppression of whole body fat oxidation $(16,17)$. If muscle fat oxidation were decreased to a similar extent after glucose ingestion, a substantial proportion of the oral glucose taken up by muscle would have to be oxidized to compensate for the reduced oxidation of fat.

The present studies were, therefore, undertaken to test the 
hypothesis that oxidation is the major fate of oral glucose taken up by muscle and to more precisely characterize the disposition of ingested glucose. For this purpose, we employed an approach that combined the use of isotope dilution, forearm balance, and indirect calorimetric techniques to quantitate the extent to which muscle glycogenic, glycolytic, and oxidative pathways, as well as splanchnic uptake, were responsible for the overall disposal of an oral glucose load in normal human volunteers. Our results indicate that oxidation is the predominant fate of oral glucose taken up by muscle and that contrary to the prevailing view, muscle is neither the major site of storage nor the major site of disposal of an oral glucose load.

\section{Methods}

Subjects. Informed written consent was obtained from nine healthy volunteers (four female, five male), who were $27.7 \pm 2.6 \mathrm{yr}$ old and weighed $74.4 \pm 5.6 \mathrm{~kg}$. All were nonobese (ideal body weight, $110 \pm 4 \%$, Metropolitan Life Insurance Co. tables, 1985) and had no family history of diabetes mellitus. Six of the nine subjects exercised two to four times a week on a noncompetitive basis, but none participated in strenuous physical activity for at least $24 \mathrm{~h}$ before study.

Protocol. The subjects were admitted to the inpatient facility of the Clinical Research Center, the evening before experiments, having consumed a weight-maintenance diet containing at least $200 \mathrm{~g}$ carbohydrate for the preceding $3 \mathrm{~d}$. After a standard dinner $(10 \mathrm{kcal} / \mathrm{kg}, 50 \%$ cholesterol, $35 \%$ fat, and $15 \%$ protein) between 5 and 7 p.m., the subjects received only water for the subsequent $12-14 \mathrm{~h}$ until experiments were begun.

At $\sim 5$ a.m. the next morning, an 18-gauge intravenous catheter was inserted into a superficial forearm vein for initiation of a primed $(28 \mu \mathrm{Ci})$, continuous $(0.40 \mu \mathrm{Ci} / \mathrm{min})$ infusion of $\left[6-{ }^{3} \mathrm{H}\right] \mathrm{glucose}(\mathrm{New}$ England Nuclear, Boston, MA) to permit determination of the overall rates of glucose appearance. The ipsilateral radial artery was cannulated with a 20-gauge arterial catheter (Arrow International, Inc., Greensboro, PA) for intermittent arterial sampling. In the contralateral arm, a large antecubital vein was cannulated in a retrograde direction for intermittent sampling of the deep venous system of the forearm. Slow saline infusions without added heparin were infused to maintain patency. After a 3-h isotope equilibration period, each subject ingested over a 5-min period an oral glucose solution (Dextrol, $200 \mathrm{ml}, 1 \mathrm{~g} / \mathrm{kg}$, maximum $75 \mathrm{~g}$; American Scientific Products, McGaw Park, IL) containing $100 \mu \mathrm{Ci}\left[1-{ }^{14} \mathrm{C}\right]$ glucose (Research Products Intl., Gif sur Yvette, France) for the determination of the rate of appearance of the ingested glucose. Subjects remained supine throughout the experiment. Simultaneous arterial and venous blood was obtained at 30 - or 60 -min intervals before and over a 5-h period after glucose ingestion for determination of glucose, $\left[{ }^{14} \mathrm{C}\right]$ glucose specific activity, $\left[{ }^{3} \mathrm{H}\right]$ glucose specific activity, alanine, lactate, pyruvate, $\mathrm{O}_{2}, \mathrm{CO}_{2}$, and insulin concentrations.

Forearm blood flow. Blood flow of the proximal forearm was determined at each blood sampling using electrocapacitance plethysmography (18) after the procedure described by Jackson et al. (10): in brief, the arm was maintained in a resting position with an electrocapacitance plethysmography cuff fitted to the circumference of the proximal forearm. A pediatric sphygmomanometer cuff (child size Baumanometer cuff; W. B. Baum Co., Caplauge, NY) was inflated to $240 \mathrm{mmHg}$ at the wrist beginning 2 min before flow measurements and continued until completion of venous sampling in order to exclude hand blood flow and metabolites from forearm measurements. Blood flow was measured with a sphygmomanometer cuff (Baumnanometer calibrated V-lok; W. A. Baum Co.) placed on the upper arm and inflated to $50 \mathrm{mmHg}$. This cuff was deflated at least $1 \mathrm{~min}$ before venous sampling. Calibration of the apparatus was performed at least hourly by injecting known volumes of saline into a bladder applied to the inner surface of the plethysmography cuff. Linearity of response was demonstrated by using sequential graded injection volumes. Three flow measurements were made at each time point and the mean value was used. Blood flow was determined as milliliters per minute per 100 $\mathrm{ml}$ forearm tissue. The forearm circumference was measured at the proximal and distal borders of the plethysmography cuff and the contained volume calculated using the equation for a truncated cone.

Whole body glucose and lipid oxidation. Whole body glucose oxidation was determined at 30-min intervals throughout the experiments by means of indirect calorimetry (19-21) using a metabolic measurement cart (Sensor Medic, Anaheim, CA) equipped with a polarographic $\mathrm{O}_{2}$ sensor, an infrared $\mathrm{CO}_{2}$ analyzer, and an inline turbo transducer for determination of expired gas volume. The machine was calibrated immediately before each experiment and at $45-\mathrm{min}$ intervals throughout the experiment. For $15 \mathrm{~min}$ before each blood sampling, the subject's expired air was collected by means of a comfortable yet tightly sealed mask that covered the nose and mouth. After application of the mask, the pattern of breathing was allowed to stabilize for several minutes as determined by demonstration of a constant minute volume. A 9-min continuous measurement was made and the mean value was used for calculations. Nonprotein respiratory quotient was calculated from the calorimetric values and urinary nitrogen excretion (19). Glucose and lipid oxidation were determined from the tables of Lusk (20). It was presumed that glucose not oxidized was stored (16, 17). The assumptions and limitations of this use of indirect calorimetry have been discussed in detail elsewhere (21).

\section{Analytical procedures}

Samples for glucose, intermediary metabolites (lactate, alanine, and pyruvate), and glucose specific activity were collected into $\mathrm{NaF}$-oxalate tubes, placed on ice, and centrifuged at $4^{\circ} \mathrm{C}$. Plasma was separated, aliquoted, and stored at $-20^{\circ}$ and $-70^{\circ} \mathrm{C}$ for later analysis of glucose specific activity and intermediary metabolites, respectively. Plasma glucose was determined in duplicate by a glucose oxidase method (YSI glucose analyzer; Yellow Springs Instruments, Yellow Springs, $\mathrm{OH}$ ). Plasma lactate was determined with a YSI lactate analyzer (Yellow Springs Instruments); plasma alanine (22) and pyruvate (23) were determined microflurometrically. Plasma insulin was determined by radioimmunoassay (24). Blood for $\mathrm{O}_{2}$ and $\mathrm{CO}_{2}$ content were collected in an air-free manner into heparinized syringes, placed in ice, and analyzed immediately using an IL282 CO-Oximeter and an IL813 pH/ Blood Gas Analyzer (Instrumentation Laboratory, Lexington, MA). The coefficient of variation for determinations of $\mathrm{O}_{2}$ and $\mathrm{CO}_{2}$ was 0.5 and $1.0 \%$, respectively, over the range of values examined in the present experiments; the accuracy was $\pm 0.7 \mathrm{ml} / 100 \mathrm{ml}$ for $\mathrm{O}_{2}$ and \pm 0.2 $\mathrm{ml} / 100 \mathrm{ml}$ for $\mathrm{CO}_{2}$. Deep venous oxygen content did change throughout the experiment $(11.6 \mathrm{ml} / 100 \mathrm{ml}$ before glucose ingestion, $\sim 12$ $\mathrm{ml} / 100 \mathrm{ml}$ after glucose ingestion).

Plasma for determination of $\left[{ }^{3} \mathrm{H}\right]-$ and $\left[{ }^{14} \mathrm{C}\right]$ glucose specific activity was deproteinized with an equal volume of chilled $7 \%$ perchloric acid, neutralized with $\mathrm{KOH}$, and passed through cation (AG-50-X8) and anion (Ag-1-X8) exchange columns (Bio-Rad Laboratories, Richmond, CA) to remove charged compounds (25). The eluate was evaporated (Speedvac Concentrator; Savant Instruments, Hicksville, NY) to remove tritiated $\mathrm{H}_{2} \mathrm{O}$ and then reconstituted in $2 \mathrm{ml}$ distilled $\mathrm{H}_{2} \mathrm{O}$. A $1-\mathrm{ml}$ aliquot was counted for ${ }^{3} \mathrm{H}$ and ${ }^{14} \mathrm{C}$ disintegrations per minute by dual channel scintillation spectrometry after addition of $10 \mathrm{ml}$ scintillation solvent (RPI, Mount Prospect, IL) with correction for quench. Another 1-ml aliquot was used to determine recycling of the ${ }^{14} \mathrm{C}$-label by determining ${ }^{14} \mathrm{C}$ in the sixth carbon of plasma glucose using periodate degradation and dimedon trapping according to the method of Bloom (26). Adjustment for efficiency of the degradation and subsequent dimedon reaction was made by concurrently measuring recovery of ${ }^{3} \mathrm{H}$ on carbon 6 . The amount of $6-{ }^{14} \mathrm{C}$ disintegrations per minute, multiplied by four according to the equation of Reichert (27), was subtracted from the total ${ }^{14} \mathrm{C}$ disintegrations per minute to obtain $1-{ }^{14} \mathrm{C}$ glucose disintegrations per minute. As previously found by other investigators $(11,28,29)$, recycling did not exceed $10 \%$ of total ${ }^{14} \mathrm{C}$ disintegrations per minute. 
Calculations. The rates of overall glucose appearance (endogenous plus exogenous) were calculated using the nonsteady state equations of Hetenyi and Norwich (30) from $\left[6-{ }^{3} \mathrm{H}\right]$ glucose data, since this approach has been shown to provide a good approximation of glucose turnover in the nonsteady state (30). The rate of appearance of the oral glucose in the systemic circulation was calculated from $\left[1-{ }^{14} \mathrm{C}\right]$ glucose data, after correction for recycling, with the equation of Chiasson et al. (31), the derivation of which has been described in detail (31); this represents a modification of standard equations in which disintegrations per minute per milliliter is substituted for concentration of unlabeled glucose to trace the appearance of a labeled substance instead of unlabeled glucose. Endogenous glucose production was calculated as the difference between the overall rate of glucose appearance $\left(\left[6-{ }^{3} \mathrm{H}\right]-\right.$ glucose data) and the rate of appearance of exogenous glucose ([1${ }^{14} \mathrm{Clglucose}$ data $)(11,28,29,32)$.

Overall splanchnic glucose uptake was calculated as the difference between the amount of oral glucose administered and the total systemic appearance of the oral glucose $(11,28,29)$. It was assumed that absorption of the orally administered glucose was completed within the 5-h experimental period $(32,33)$.

The forearm balance of substrates was calculated at each time as the product of the arteriovenous difference and the forearm blood flow. Plasma concentrations were converted to whole blood values using the equation: whole blood value equals plasma value times $(1-0.0294$ hematocrit) (34). The area under the curve was measured for each substrate to determine the overall net balance of each substrate during the 5-h experimental period. The net balance for lactate, alanine, and pyruvate, expressed as glucose equivalents (e.g., $2 \mathrm{~mol}$ lactate equals $1 \mathrm{~mol}$ glucose), was divided by net glucose balance to calculate the fraction of glucose uptake that was released as glycolytic intermediates. It was assumed that under the postprandial conditions of hyperinsulinemia and hyperglycemia, proteolysis was suppressed and did not contribute significantly to the release of alanine and lactate (35). Forearm oxidation of lipid and carbohydrate were calculated using the table of Lusk (20) and the forearm RQ and oxygen consumption (19). The area under the glucose oxidation curve over the 5-h experimental period was divided by total net forearm glucose uptake to determine the fraction of glucose taken up by the forearm that was oxidized.

Forearm uptake of glucose derived from the oral load was calculated as the product of overall net forearm glucose uptake and the fraction of the arterial glucose content derived from the oral load. The latter was determined at each sampling time as the ratio of arterial $\left[1-{ }^{14} \mathrm{C}\right]$ glucose specific activity to $1-{ }^{14} \mathrm{C}$-specific activity of the oral glucose load (31). It was assumed that, after uptake by the forearm tissues, orally derived glucose and endogenous glucose were metabolized identically and, therefore, that the fractions of overall forearm glucose uptake that were oxidized, stored, and released as glycolytic intermediates were identical for orally derived glucose and endogenous glucose.

Forearm data per $100 \mathrm{ml}$ of tissue were converted to values per kilogram forearm muscle, assuming that $80 \%$ of the measured forearm blood flow perfused muscle (36) and that muscle comprised $60 \%$ of the measured forearm volume (15). Assuming that forearm muscle was representative of muscle elsewhere in the body, these values were multiplied by total body skeletal muscle mass, then calculated from midarm circumference and triceps skinfold thickness using the equation of Heymsfield et al. (37) to obtain values for total body skeletal muscle. The validity of these assumptions has been described in detail elsewhere $(15,36)$.

The amount of whole body glucose oxidation attributable to the orally derived glucose was calculated as the product of whole body glucose oxidation and the fraction of the arterial glucose content derived from the oral glucose (see above). The amount of the oral glucose load that was stored was calculated as the difference between the total glucose ingested and the amount of the ingested glucose that was oxidized.

Data in text and figures are presented as mean \pm SEM and their statistical significance was analyzed using paired Student's $t$ tests; a $P<0.05$ was considered significant.

\section{Results}

\section{Plasma glucose and insulin concentrations (Fig. 1)}

After ingestion of glucose, arterial plasma glucose increased from $5.3 \pm 0.1 \mathrm{mmol} /$ liter to a peak value of $8.9 \pm 0.5 \mathrm{mmol} /$ liter at $60 \mathrm{~min}(P<0.01)$, and returned to basal levels by 240 min. Plasma insulin followed a similar pattern, increasing sixfold from $6.4 \pm 0.5$ to $37.4 \pm 5.9 \mu \mathrm{U} / \mathrm{ml}$ at $90 \mathrm{~min}(P<0.01)$ and returning to basal values by $240 \mathrm{~min}$.

\section{Rates of endogenous, exogenous, and overall glucose appearance (Fig. 1)}

Basal (endogenous) glucose appearance averaged 10.9 \pm 0.2 $\mu \mathrm{mol} / \mathrm{kg}$ per min. After ingestion of glucose, overall glucose appearance increased to a peak value of $26.3 \pm 1.4 \mu \mathrm{mol} / \mathrm{kg}$ per $\mathrm{min}$ at $90 \mathrm{~min}(P<0.01)$ and returned to basal values by 240 $\mathrm{min}$. The rate of appearance of the exogenous (orally administered) glucose increased within $30 \mathrm{~min}$ to a peak rate of $24.4 \pm 1.4 \mu \mathrm{mol} / \mathrm{kg}$ per $\mathrm{min}$ at $60 \mathrm{~min}(P<0.01)$ and then progressively decreased to $2.2 \pm 0.3 \mu \mathrm{mol} / \mathrm{kg}$ per min at 300 min. Endogenous glucose production decreased $\sim 40 \%$ at 30 min $(P<0.02)$, reaching a nadir $(>85$ percent suppression, $1.5 \pm 0.3 \mu \mathrm{mol} / \mathrm{kg}$ per $\mathrm{min}$ ) at $90 \mathrm{~min}$, and was still significantly suppressed $30 \%$ below basal values at $300 \mathrm{~min}(7.9 \pm 0.5 \mu \mathrm{mol} /$ kg per min, $P<0.01$ ).

\section{Muscle glucose metabolism (Figs. 2 and 3, Table I)}

Forearm arterial and venous concentrations and the balance of glucose and glycolytic intermediates (alanine, lactate and pyruvate) are given in Fig. 2. Forearm blood flow (Fig. 3) did not change significantly during experiments and averaged $2.8 \pm 0.3$ $\mathrm{ml} / \mathrm{min}$ per $100 \mathrm{ml}$ of tissue, comparable with values reported by other investigators $(11,15)$.

Glucose uptake. Forearm glucose uptake increased from a basal rate of $0.45 \pm 0.08 \mu \mathrm{mol} / \mathrm{min}$ per $100 \mathrm{ml}$ tissue to a peak

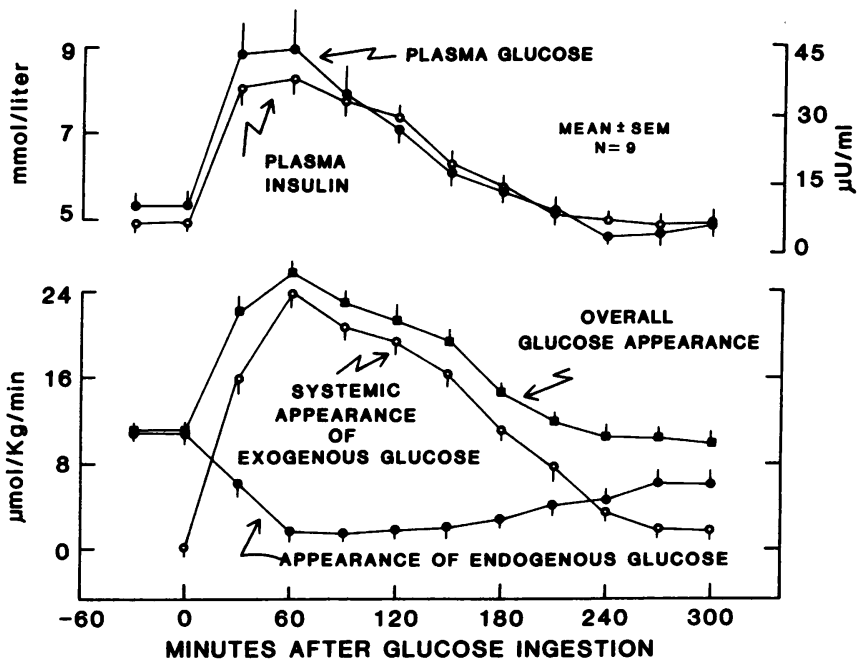

Figure 1. Plasma glucose and insulin concentrations and rates of systemic appearance of endogenous glucose, orally administered glucose, and oral plus endogenous glucose after ingestion of a $1-\mathrm{g} / \mathrm{kg}$ glucose load in nine normal volunteers. 


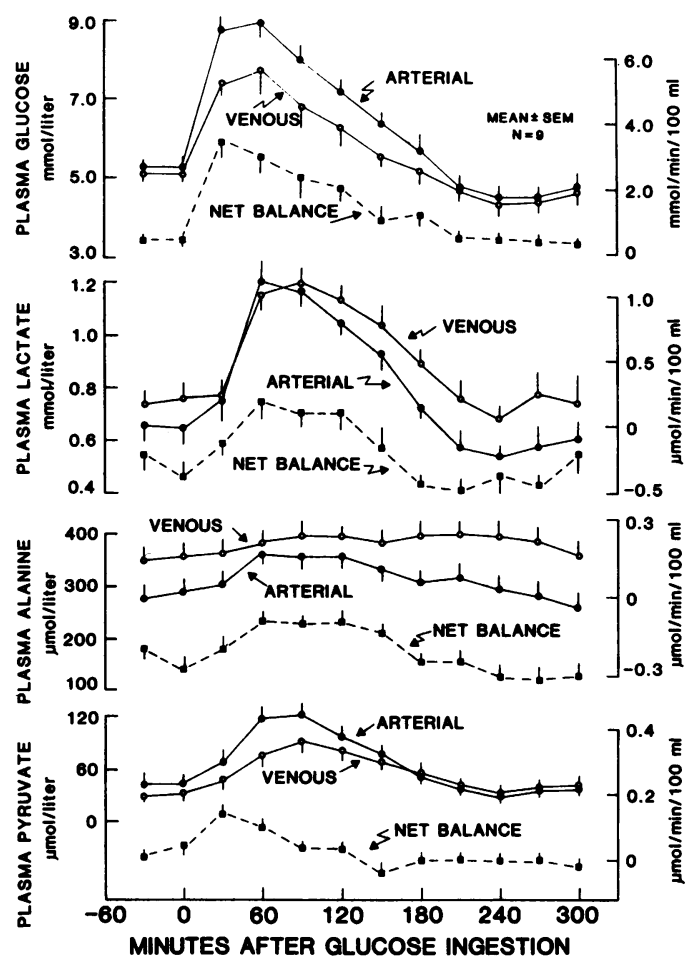

Figure 2. Arterial and venous concentrations and net balance of glucose, lactate, alanine, and pyruvate across the forearm after ingestion of a $1-\mathrm{g} / \mathrm{kg}$ glucose load in nine normal volunteers.

value of $3.51 \pm 0.31 \mu \mathrm{mol} / \mathrm{min}$ per $100 \mathrm{ml}$ at $30 \min (P<0.01)$, and returned to basal values by $210 \mathrm{~min}$. During the 5 -h experimental period (Table I), overall glucose uptake was $406 \pm 59$ $\mu \mathrm{mol} / 100 \mathrm{ml}$; of this, $268 \pm 43 \mu \mathrm{mol} / 100 \mathrm{ml}$ was oral glucose. Total body muscle mass, calculated from mid-arm circumference and triceps skinfold thickness using the equation of Heymsfield et al. (36), was $27 \pm 3 \mathrm{~kg}$. Based on this value, $17.9 \pm 2.9 \mathrm{~g}$, or $\sim 25 \%$ of the oral load was taken up by muscle.

Glycolysis. Before ingestion of glucose, the forearm released lactate and alanine at rates of $0.38 \pm 0.12$ and $0.28 \pm 0.06$ $\mu \mathrm{mol} / \mathrm{min}$ per $100 \mathrm{ml}$ tissues, respectively. After ingestion of

Table I. Muscle Glucose Metabolism during Assimilation of Oral Glucose Load

\begin{tabular}{lcccrrr}
\hline & \multicolumn{2}{c}{$\begin{array}{c}\text { Forearm tissue } \\
(\mu \mathrm{mol} / 100 \mathrm{ml})^{*}\end{array}$} & & \multicolumn{1}{c}{ Total body muscle $(g)$} \\
\cline { 2 - 3 } \cline { 6 - 7 } & Overall & Oral glucose & & Overall & Oral glucose \\
\hline Uptake & $406 \pm 59$ & $268 \pm 43$ & & $27.3 \pm 4.3$ & $17.9 \pm 2.9$ \\
Glycolysis & $60.2 \pm 16.6$ & $37.9 \pm 11.5$ & & $4.0 \pm 1.5$ & $2.5 \pm 0.9$ \\
Lactate release & $35.6 \pm 12.2$ & $22.9 \pm 7.8$ & & $2.3 \pm 1.1$ & $1.5 \pm 0.7$ \\
Alanine release & $30.5 \pm 6.0$ & $18.9 \pm 3.6$ & & $2.1 \pm 0.5$ & $1.3 \pm 0.3$ \\
Pyruvate release & $-6.4 \pm 2.9$ & $-4.0 \pm 1.8$ & & $0.4 \pm 0.2$ & $-0.3 \pm 0.1$ \\
Oxidation & $208 \pm 28$ & $138 \pm 22$ & & $13.6 \pm 2.0$ & $8.9 \pm 1.4$ \\
Storage & $138 \pm 54$ & $91.5 \pm 35.4$ & & $9.8 \pm 3.7$ & $6.4 \pm 2.3$
\end{tabular}

* Micromoles as glucose equivalents calculated as (a) sum of lactate, alanine, and pyruvate release, $(b)$ glucose uptake minus glycolysis plus oxidation, and $(c)$ as described in Methods. glucose, there was a transient decrease in release of both of these substrates lasting $120-180 \mathrm{~min}(P<0.05)$. During the 5-h experimental period (Table I), net overall lactate and alanine release was $35.6 \pm 12$ and $30.5 \pm 6.0 \mu \mathrm{mol}$ glucose equivalents per $100 \mathrm{ml}$, respectively. Of this, $22.9 \pm 7.8$ (lactate) and $18.7 \pm 3.6$ (alanine) $\mu \mathrm{mol}$ glucose equivalents per $100 \mathrm{ml}$ were derived from the oral glucose. There was a small net uptake of pyruvate by the forearm in the postabsorptive state $(0.05 \pm 0.02$ $\mu \mathrm{mol} / \mathrm{min}$ per $100 \mathrm{ml}$ ); this increased transiently after ingestion of glucose $(P<0.05)$, so that over the 5 -h experimental period $6.4 \pm 2.9 \mu \mathrm{mol}$ glucose equivalents per $100 \mathrm{ml}$ were taken up (Table I): of this, $4.0 \pm 1.8 \mu \mathrm{mol}$ glucose equivalents per $100 \mathrm{ml}$ were derived from the oral glucose. Extrapolation of these values for forearm lactate, alanine, and pyruvate balance to whole body indicated that $2.5 \pm 0.9 \mathrm{~g}$, or $\sim 15 \%$ of the $17.9 \mathrm{~g}$ oral glucose taken up by muscle was released as glycolytic intermediates.

Glucose oxidation and storage. Forearm $\mathrm{O}_{2}$ and $\mathrm{CO}_{2}$ arteriovenous differences, respiratory quotient, and glucose oxidation calculated via indirect calorimetry, as well as whole body nonprotein respiratory quotient and glucose oxidation calculated by indirect calorimetry, are given in Fig. 3. Forearm $\mathrm{O}_{2}$ arteriovenous difference did not change significantly during the experiment and averaged $6.9 \pm 0.2 \mathrm{ml} / 100 \mathrm{ml}$ tissue. Fore$\operatorname{arm} \mathrm{CO}_{2}$ arteriovenous difference increased significantly after glucose ingestion from a basal postabsorptive value of 5.9 \pm 0.4 $\mathrm{ml} / 100 \mathrm{ml}$ to a peak of $7.4 \pm 0.5 \mathrm{ml} / 100 \mathrm{ml}$ at $30 \mathrm{~min}(P$ $<0.01$ ), and subsequently returned to basal values by $240 \mathrm{~min}$. Forearm RQ in the postabsorptive state was $0.80 \pm 0.08$, similar to values in normal volunteers found by Andres et al. (15) for forearm and Lyngsoe et al. for leg (38). After glucose ingestion, the RQ increased to a peak of $1.07 \pm 0.05$ at $60 \mathrm{~min}(P$ $<0.01$ ) and returned to baseline at $240 \mathrm{~min}$.

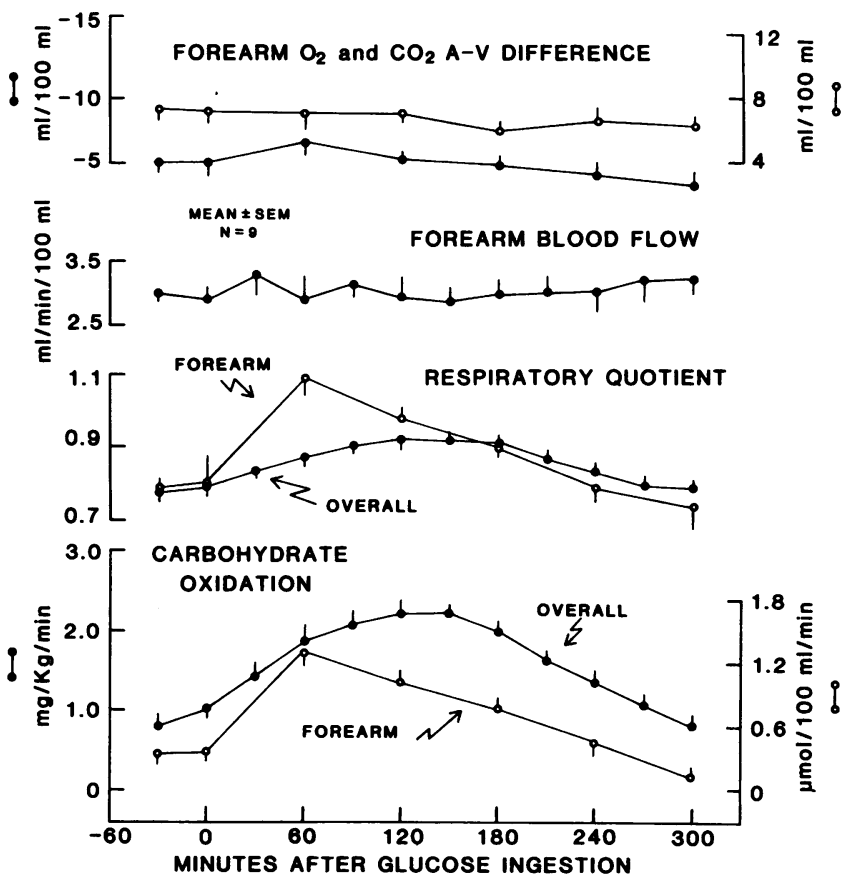

Figure 3. Forearm $\mathrm{O}_{2}$ and $\mathrm{CO}_{2}$ arteriovenous differences, blood flow, respiratory quotient and carbohydrate oxidation, and overall (whole body) respiratory quotient and carbohydrate oxidation after ingestion of $1 \mathrm{~g} / \mathrm{kg}$ glucose in nine normal volunteers. 
Forearm glucose oxidation in the postabsorptive state was $0.44 \pm 0.10 \mu \mathrm{mol} / \mathrm{min}$ per $100 \mathrm{ml}$ of tissue; after ingestion of glucose, it increased threefold to a peak value of $1.21 \pm 0.3$ $\mu \mathrm{mol} / \mathrm{min}$ per $100 \mathrm{ml}$ at $60 \mathrm{~min}(P<0.01)$, and subsequently returned to basal values between 240 and $300 \mathrm{~min}$. During the 5-h experimental period, forearm glucose oxidation totaled $208 \pm 28 \mu \mathrm{mol} / 100 \mathrm{ml}$, of which $138 \pm 22 \mu \mathrm{mol} / 100 \mathrm{ml}$ was attributable to oral glucose. Extrapolation of this value to total body (Table I) indicated that $8.9 \pm 1.4 \mathrm{~g}$, or $\sim 50 \%$ of the $17.9 \mathrm{~g}$ oral glucose taken up by muscle, was oxidized. Subtraction of the oral glucose oxidized $(8.9 \mathrm{~g})$ and the oral glucose released as glycolytic intermediated $(2.5 \mathrm{~g})$ from the total oral glucose taken up by muscle $(17.9 \mathrm{~g})$ left $6.4 \pm 2.3 \mathrm{~g}$, or $\sim 35 \%$ of the oral glucose taken up by muscle available for storage. Thus, of the 67.6-g oral glucose load, $\sim 10 \%$ could be accounted for as muscle glycogen.

Fat oxidation. In the postabsorptive state, forearm fat oxidation averaged $72 \pm 12 \mu \mathrm{g} / 100 \mathrm{ml}$ tissue/min; after ingestion of glucose, it decreased $>80 \%$ to $10 \pm 4 \mu \mathrm{g} / 100 \mathrm{ml}$ tissue $/ \mathrm{min}$ at $120 \mathrm{~min}$, and returned to basal values by $240 \mathrm{~min}(69 \pm 19$ $\mu \mathrm{g} / 100 \mathrm{ml} / \mathrm{min}$ ). During the $5-\mathrm{h}$ postprandial period, forearm fat oxidation was decreased $>50 \%$, averaging $34 \pm 6 \mu \mathrm{g} / 100$ $\mathrm{ml} / \mathrm{min}, P<0.01$.

\section{Splanchnic glucose metabolism (Table II)}

The overall systemic appearance of glucose during the 5-h experimental period was $66.5 \pm 4.6 \mathrm{~g}$. Of this, endogenous glucose accounted for $28 \%(18.5 \pm 1.6 \mathrm{~g})$ and oral glucose accounted for $72 \%(48.2 \pm 3.2 \mathrm{~g})$. Since the dual isotope technique measures only first pass uptake, the difference between the $67.7 \mathrm{~g}$ glucose administered orally and the $48.2 \mathrm{~g}$ of the oral glucose that appeared systemically $(19.4 \pm 1.3 \mathrm{~g}$, or $29 \%$ of the oral glucose load) represents a minimal estimate of the oral glucose retained in the splanchnic bed. Endogenous glucose production was suppressed an average of $58 \pm 2 \%$ during the 5-h postprandial period, resulting in splanchnic conservation of $25.7 \pm 1.6 \mathrm{~g}$ glucose.

Whole body glucose and fat oxidation and glucose storage (Fig. 3)

Whole body RQ in the postabsorptive state was $0.80 \pm 0.01$; after ingestion of glucose, it increased to a maximum of

Table II. Splanchnic Glucose Metabolism during Assimilation of an Oral Glucose Load

\begin{tabular}{lcr}
\hline & Percent & $\mathrm{g} / 5 \mathrm{~h}$ \\
\hline $\begin{array}{l}\text { Overall systemic glucose appearance } \\
\text { (endogenous and exogenous) }\end{array}$ & & $66.5 \pm 4.6$ \\
$\begin{array}{l}\text { Baseline endogenous glucose appearance } \\
\text { Endogenous glucose appearance after } \\
\quad \text { oral glucose }\end{array}$ & & $44.2 \pm 2.9$ \\
$\begin{array}{l}\text { Suppression of endogenous glucose } \\
\text { appearance }\end{array}$ & & $18.5 \pm 1.6$ \\
$\begin{array}{l}\text { Endogenous glucose not released } \\
\text { Glucose administered orally }\end{array}$ & $58.4 \pm 1.5$ & \\
$\begin{array}{l}\text { Oral glucose appearing systemically } \\
\text { Oral glucose taken up by splanchnic bed }\end{array}$ & & $25.7 \pm 1.8$ \\
$\begin{array}{l}\text { Proportion of oral load taken up by } \\
\text { splanchnic bed }\end{array}$ & & $67.6 \pm 2.7$ \\
Overall glucose retained by splanchnic & & $19.4 \pm 3.2$ \\
bed (endogenous and exogenous) & & \\
\hline
\end{tabular}

$0.92 \pm 0.02$ at $120 \mathrm{~min}(P<0.01)$ and returned to baseline by $270 \mathrm{~min}$. Glucose oxidation in the postabsorptive state was $5.6 \pm 0.6 \mu \mathrm{mol} / \mathrm{kg}$ per min. During the 5 -h experimental period, a total of $37.7 \pm 4.0 \mathrm{~g}$ of glucose was oxidized; $24.9 \pm 2.3 \mathrm{~g}$ was attributable to the oral glucose. This amount of glucose oxidation left $42.8 \pm 2.7 \mathrm{~g}$, or $63 \pm 3 \%$ of the oral glucose load available for storage. During the 5-h postprandial period, whole body fat oxidation decreased $35 \%$, averaging $0.60 \pm 0.06$ $\mathrm{mg} / \mathrm{kg}$ per min compared with $0.92 \pm 0.08 \mathrm{mg} / \mathrm{kg}$ per min in the postabsorptive state $(P<0.01)$.

\section{Discussion}

Ingestion of glucose normally suppresses release of endogenous glucose from the liver $(11,28,29)$ and reduces the oxidation of fat $(16,17)$. To the extent that this occurs, ingested glucose must be substituted for endogenous glucose and fat to satisfy tissue energy requirements. Since fat is the major energy source for muscle in the postabsorptive state (15), we postulated that oxidation rather than storage would be the predominant fate of ingested glucose in muscle. To test this hypothesis and to more precisely characterize the metabolic fate of an oral glucose load, we employed a dual isotope technique (31), which permitted measurements of endogenous glucose output, the appearance of orally administered glucose in the systemic circulation, and the proportion of plasma glucose derived from the ingested glucose. This approach, in conjunction with use of indirect calorimetry and determination of substrate balance across the forearm, enabled us to calculate uptake of the orally administered glucose by muscle and the splanchnic bed, as well as the relative proportions of the oral glucose that were oxidized, stored, or released as glycolytic intermediates from muscle.

Muscle glucose metabolism. Over the 5-h experimental period, the forearm took up $73 \mathrm{mg}(406 \mu \mathrm{mol}) / 100 \mathrm{ml}$ of tissue; extrapolation of this value to whole body muscle, assuming (as have other investigators) $(10,11,15,29,39)$ that $80 \%$ of measured forearm flow was muscle and that $60 \%$ of the measured forearm was muscle, yielded a value of $27 \mathrm{~g}$ for whole body muscle glucose uptake. This value, of course, includes both oral and endogenous glucose. When the endogenous component is subtracted from knowledge of the proportion of plasma glucose due to the oral glucose, $\sim 18 \mathrm{~g}$, or $26 \%$ of the oral load was found to be taken up by muscle.

This value is comparable with the $33-46 \%$ estimated by other investigators $(10,11,28,29,39)$ on the basis of forearm or leg glucose extraction data, given the fact that the endogenous glucose component was not subtracted in those studies. However, these values are substantially less than that reported by Katz et al. (5). These investigators estimated, on the basis of leg glucose extraction data, that muscle took up $65 \mathrm{~g}$ of a 92-g load $(71 \%)$. The latter value would appear to be in error, since it approximated the total splanchnic glucose output in their subjects and brain alone would have taken up $>15 \mathrm{~g}$ during their experiment (40-42).

A possible explanation for the discrepant results of Katz et al. (5) is that these investigators did not take into consideration leg blood flow distribution and leg tissue composition, and they did not subtract from their total leg glucose uptake the component due to endogenous glucose. Recalculation of their data, taking these factors into consideration, would give a 
value of $31 \mathrm{~g}$, or $\sim 34 \%$ of the $92-\mathrm{g}$ oral load for muscle glucose uptake, which is more in line with the results of previous studies $(10,11,29,39)$.

Although currently available data thus indicate that $25-30 \%$ of an oral glucose load is disposed of in muscle, the metabolic fate of the glucose taken up by muscle has not been previously studied in detail. The measurement of forearm balance of lactate, alanine, pyruvate, $\mathrm{O}_{2}$, and $\mathrm{CO}_{2}$ in the present experiments permitted calculation of the relative amounts of the oral glucose that underwent glycolysis, oxidation, and storage in muscle. Of the $18 \mathrm{~g}$ oral glucose taken up by muscle in the present study, $\sim 15 \%$ was released as either lactate, alanine, or pyruvate (glycolysis); an additional $8.9 \mathrm{~g}$, or $\sim 50 \%$ of uptake was oxidized. This left $6.4 \mathrm{~g}$, or $\sim 35 \%$ of the amount taken up available for storage.

That oxidation should be the predominant fate of ingested glucose in muscle is consistent with the fact that after glucose ingestion there is a marked suppression of fat oxidation (16, 17). In the present study, whole body fat oxidation decreased $35 \%$, equivalent to $\sim 6 \mathrm{~g}$ over the $5-\mathrm{h}$ experimental period. During the same period, oxidation of fat by the forearm was decreased $>50 \%$. This value would predict a decrease of $\sim 4 \mathrm{~g}$ of fat oxidation by muscle tissue. Thus, the decrement in whole body fat oxidation can be largely accounted by the decrement in muscle fat oxidation. Oxidation of the glucose taken up by muscle would, therefore, be needed to compensate for diminished fat oxidation in order to satisfy muscle energy requirements.

The value that we obtained for storage of glucose in muscle does not appear to be an underestimation, since it could account for complete replenishment of muscle glycogen stores that had been depleted during the overnight fast. In the basal period, we found a net negative glucose balance of $0.30 \mu \mathrm{mol} /$ min per $100 \mathrm{ml}$ tissue, comparable with those found by Andres et al. (15) for forearm and Lyngsoe et al. (38) for leg. Extrapolation of these data would indicate that overnight there had been $\sim 11 \mathrm{~g}$ depletion of body muscle glycogen, a value quite comparable with the overall amount of glucose that we found was stored in muscle $(\sim 10 \mathrm{~g})$.

It is well established the arterial lactate concentrations increase after glucose ingestion (10-12, 43, 44). In the present study, net forearm output of lactate decreased as arterial lactate increased. This observation and those of Jackson et al. (10, 11) and Radziuk et al. (12), demonstrating only a small amount of lactate release from forearm tissues after an oral glucose load in human volunteers, would argue strongly against muscle lactate release being a major factor responsible for the rise in arterial lactate concentrations.

Although it is currently thought that hepatic glycogen is formed predominantly via a so-called indirect pathway from 3-carbon gluconeogenic precursors (6), the source of these precursors has not been established. One potential source could be Cori cycle and glucose-alanine cycle activity in muscle $(27,35)$. The findings in the present study of only $4 \mathrm{~g}$ of alanine, lactate, and pyruvate net output by muscle indicate that muscle cannot be a major source of 3-carbon fragments for postprandial hepatic glycogen repletion via the so-called indirect pathway (6). Recent studies (43-45) suggest that splanchnic tissues may be important. However, the situation may be different in the postabsorptive state. In the present studies, muscle released $185 \mu \mathrm{mol} / \mathrm{min}$ of lactate, alanine, and pyruvate. Since gluconeogenesis averages $\sim 280 \mu \mathrm{mol} / \mathrm{min}$ in normal volunteers (46), muscle could supply as much as twothirds of the 3-carbon precursors used for gluconeogenesis in the postabsorptive state.

Splanchnic glucose metabolism. In the present studies, $48.2 \pm 3.2 \mathrm{~g}$ of the $67.6 \pm 2.7$ oral glucose load administered $(71 \%)$ appeared in the systemic circulation over $5 \mathrm{~h}$. All of the oral glucose should have been absorbed during this period (32, 33). Therefore, the difference between the amount ingested and the amount appearing in the systemic circulation, $19.4 \pm 1.3 \mathrm{~g}$, or nearly $30 \%$ of the oral load, can be considered to have been disposed of within the splanchnic bed. Although this percentage was not significantly greater than that attributable to muscle, it should be pointed out that this value probably underestimates the overall splanchnic contribution to disposition of the oral load since our calculation represents only initial splanchnic extraction (32) and does not include splanchnic uptake of glucose from the systemic pool.

Our results agree quite well with the results of several recent studies examining splanchnic glucose uptake over a comparable period of time using either the hepatic venous catheter technique $(5,28)$ or an isotopic approach $(11,28,47)$. The somewhat greater percentages for splanchnic glucose retention reported by Felig et al. (48) and Waldhausl et al. (49) can be reconciled with the above results, given the fact that in those studies splanchnic output was measured only for $2-1 / 2$ to $3 \mathrm{~h}$, in contrast to the $3-1 / 2$ to $5 \mathrm{~h}$ duration of the other studies. Since splanchnic output of oral glucose may not have been complete within $3 \mathrm{~h}(32,33)$, the experiments of Felig et al. (48) and Waldhausl et al. (49) probably overestimated splanchnic retention. Thus, if allowances are made for the different experimental conditions, the results of all the above studies indicate that splanchnic tissues are responsible for a minimal disposal of $25-30 \%$ of orally administered glucose in normal human volunteers. Indeed, values similar to these have been found recently in experiments in dogs in which hepatic glucose balance was directly measured by simultaneous portal venous and hepatic venous glucose sampling $(43,44)$.

In the present studies, endogenous glucose production was suppressed $58 \%$ over the $5-\mathrm{h}$ period after ingestion of oral glucose. This is comparable with values found in other recent studies $(11,28,29)$ that averaged $56 \%$. In the present studies, this suppression of endogenous glucose output resulted in nearly $26 \mathrm{~g}$ of glucose not being delivered into the systemic circulation. Thus, these results indicate that suppression of endogenous glucose output by splanchnic tissues is at least as important as splanchnic uptake of exogenous glucose (26 vs. $19 \mathrm{~g}$, respectively, in the present studies) in determining postprandial oral glucose tolerance.

Overview of disposition of oral glucose load. The simultaneous measurement of splanchnic and forearm glucose balance in conjunction with forearm and whole body indirect calorimetry in the present studies permit a more complete assessment of the metabolic fate of an oral load than has been previously available. Given the numerous assumptions of the techniques that we employed and some potential inaccuracies involved in extrapolation of forearm data to whole body muscle and use of values taken from other studies for brain, kidney, and heart glucose metabolism, the schema shown in Fig. 4 should not be taken as strictly quantitative. Nevertheless, as a general overview of the relative importance of various tissues 


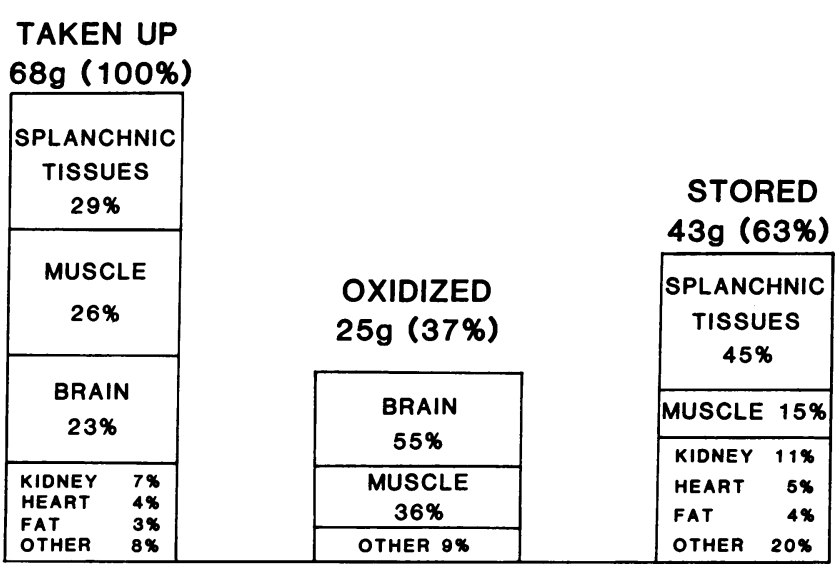

Figure 4. Overview of metabolic fate of $68-\mathrm{g}$ oral glucose load in normal human volunteers. Values for kidney storage actually represent net uptake and may include glucose that was metabolized.

in the disposal of oral glucose, the values probably represent reasonable estimates.

The data of the present study indicate that splanchnic tissues account for a minimum of $29 \%$ of the disposal of an oral glucose load and that muscle accounts for $\sim 26 \%$. Human brain, kidney, and heart have been reported to take up glucose in the postabsorptive state at rates of $83(40-42), 26(50,51)$, and $14(15) \mathrm{mg} / \mathrm{min}$, respectively. Assuming that their uptake of glucose would not decrease after glucose ingestion, and that exogenous glucose would substitute for endogenous glucose due to suppression of hepatic glucose production, brain, kidney, and heart glucose uptake could account for a minimum of 23,7 , and $4 \%$, respectively. Adipose tissue could account for another $3 \%(52)$, leaving at most $\sim 10 \%$ of the load to be disposed of by other tissues. Thus, brain, muscle, and splanchnic tissues appear to be major sites of disposal of an oral glucose load, together accounting for at least $80 \%$ of the load.

The data of the present and previous studies $(16,17$, 53-55) indicate that $30-40 \%$ of an oral glucose load is immediately oxidized; specifically, in the present studies $24.9 \mathrm{~g}$ (37\%) of a $67.6-\mathrm{g}$ oral load was oxidized. About $35 \%$ of this $(8.9 \mathrm{~g})$ could be accounted for by muscle. Since nearly all $(\sim 90 \%)$ of glucose taken up by the human brain is oxidized $(56,57)$, an additional $55 \%$ of the oxidation of the oral load (15.3 $\times 0.9 / 28.2 \mathrm{~g}$ ) could be accounted for by brain. Thus, muscle and brain together can account for $\sim 90 \%$ of the oxidation of an oral glucose load. Heart oxidizes $\sim 20 \%$ of the glucose that it takes up in the postabsorptive state (58). Assuming its basal glucose uptake $(14 \mathrm{mg} / \mathrm{min})$ would not decrease after glucose ingestion, heart could account for an additional $0.5 \mathrm{~g}$ of the oral glucose load oxidized in the present study. This would leave only between 1 and $2 \mathrm{~g}$ available for oxidation by splanchnic and other tissues.

Of the $63 \%$ of the oral glucose load $(42.8 / 67.6 \mathrm{~g})$ not oxidized in the present study and presumed to have been stored, splanchnic tissues could account for at least $45 \%$ (19.4/42.8 g). Muscle accounted for $15 \%(6.4 / 42.8 \mathrm{~g})$. Thus, contrary to a prevalent view $(5,28,29)$, muscle would not appear to play a major role in the storage of an oral glucose load. The remaining $17 \mathrm{~g}$ of the oral glucose load whose storage was not directly measured in the present study could be accounted for in the following manner: $7 \mathrm{~g}$ could be attributed to kidney $(50,51)$ and heart $(15,58)$, based on the data from other studies in which balances across these organs were made in the postabsorptive state. We have assumed that net glucose minus release of glycolytic intermediates would not increase after glucose ingestion (which would give a minimum for storage). The data of Bjorntrop and Sjostrom (53) indicate that an additional $2 \mathrm{~g}$ could be attributed to adipose tissue. This would leave $\sim 8 \mathrm{~g}$ of the load unaccounted for. Note that our estimate for splanchnic glucose storage represents a minimal estimate, since the double isotope method we used measures only first pass glucose uptake. Moreover, our calculations for splanchnic glucose storage did not include 3-carbon fragments derived from glucose that may have been incorporated into hepatic glycogen (6). Considering only the net release of $2.5 \mathrm{~g}$ of lactate, alanine, and pyruvate from muscle, our estimate of splanchnic glucose storage would increase to $51 \%$ of the storage of the oral load and leave only $\sim 10 \%$ of storage of the load unaccounted for. Given the fact that we assumed that brain, kidney, and heart glucose uptake would not increase after glucose ingestion, our calculations appear to provide a reasonable accounting of the disposition of the oral glucose load.

In summary, our results indicate that $(a)$ muscle and splanchnic tissues each take up 25-30\% of an oral glucose load, and that, (b) $50 \%$ of the glucose taken up by muscle is immediately oxidized; $15 \%$ is released as glycolytic intermediates, and $35 \%$ is stored, with the latter accounting for only $\sim 15 \%$ of the overall storage of the oral glucose. We conclude that oxidation is the predominant fate of oral glucose taken up by muscle, and that contrary to the prevalent view, muscle is neither the predominant site of storage of ingested glucose nor the major site of disposal of an oral glucose load.

\section{Acknowledgments}

We thank Cathy Butler, Pat Voelker, Linda Smith, Kay Kluge, Valarie Heiling, Teri Radam, Jane Kahl, and the staff of the Clinical Research Center, for their excellent help. We also thank Dale Brinkman, Ph.D., Sybil Chen, Ph.D., Edmund Speth, Ph.D. (all from American Hospital Supply, Irvine, CA), and Stuart Soeldner, M.D. (Harvard Medical School and Joslin Clinic, Boston, MA) for their help in formulating these studies.

This work was supported in part by grants from the U. S. Public Health Service (AM-20411, RO-00585, AM-07352, and TWO-3545) and American Hospital Study.

\section{References}

1. DeFronzo, R., R. Gunnarsson, O. Bjorkman, M. Olsson, and J. Wahren. 1985. Effects of insulin on peripheral and splanchnic glucose metabolism in noninsulin-dependent (type II) diabetes mellitus. $J$. Clin. Invest. 76:149-155.

2. Ferrannini, E., J. Wahren, P. Felig, and R. DeFronzo. 1980. The role of fractional glucose extraction in the regulation of splanchnic glucose metabolism in normal and diabetic man. Metab. Clin. Exp. 29:28-35.

3. Olefsky, J. 1985. Pathogenesis of insulin resistance and hyperglycemia in noninsulin-dependent diabetes mellitus. Am. J. Med. 79(Suppl. 3B): 1-7.

4. Cahill, G. 1970. Starvation in man. N. Engl. J. Med. 282:668675.

5. Katz, L., M. Glickman, S. Rapoport, E. Ferrannini, and R. 
DeFronzo. 1983. Splanchnic and peripheral disposal of oral glucose in man. Diabetes. 32:675-679.

6. Katz, J., and J. McGarry. 1984. The glucose paradox. Is glucose a substrate for liver metabolism? J. Clin. Invest. 74:1901-1909.

7. Lillioja, S., C. Bogardus, D. Mott, A. L. Kennedy, W. C. Knowlen, and B. V. Howard. 1985. Relationship between insulin-mediated glucose disposal and lipid metabolism in man. J. Clin. Invest. 75:1106-1115.

8. Lillioja, S., D. Mott, J. Zawadzki, A. Young, W. Abhoh, and C. Bogardus. 1986. Glucose storage is a major determinant of in vivo insulin resistance in subjects with normal glucose tolerance. J. Clin. Endocrinol. Metab. 62:922-927.

9. DeFronzo, R., E. Jacot, E. Jequier, E. Maeder, J. Wahren, and J. P. Felber. 1981. The effect of insulin on the disposal of intravenous glucose. Diabetes. 30:1000-1007.

10. Jackson, R., N. Peters, U. Advani, G. Perry, J. Rogers, W. Brough, and T. Pilkington. 1973. Forearm glucose uptake during the oral glucose tolerance test in normal subjects. Diabetes. 22:442-458.

11. Jackson, R., R. Roshania, M. Hawa, B. Sim, and L. DiSilvio. 1986. Impact of glucose ingestion on hepatic and peripheral glucose metabolism in man: an analysis based on simultaneous use of the forearm and double isotope techniques. J. Clin. Endocrinol. Metab. 63:541-549.

12. Radziuk, J., and R. Inculet. 1983. The effects of ingested and intravenous glucose on forearm uptake of glucose and glucogenic substrate in normal man. Diabetes. 32:977-981.

13. Nuttall, F., J. Borfosa, and M. Gannon. 1974. The glycogen synthase and skeletal muscle of normal humans and patients with mytotnic dystrophy: effect of glucose and insulin administration. Metab. Clin. Exp. 23:561-568.

14. Mott, D., S. Lillioja, and C. Bogardus. 1986. Overnutrition induced decrease in insulin action for glucose storage in vivo and in vitro in man. Metab. Clin. Exp. 35:160-165.

15. Andres, R., G. Cader, and K. Zierler. 1956. The quantitatively minor role of carbohydrates in oxidative metabolism by skeletal muscle in intact man in the basal state. Measurements of oxygen and glucose uptake and carbon dioxide and lactate production in the forearm. J. Clin. Invest. 35:671-682.

16. Ebiner, J., K. Acheson, A. Doerner, E. Maeder, M. Arnaud, E. Jequier, and J.-P. Felber. 1979. Comparison of carbohydrate utilization in man using direct calorimetry and mass spectrometry after an oral glucose load of $100 \mathrm{~g}$ naturally labelled [13C] glucose. Br. J. Nutr. 41:419-429.

17. Mosora, F., M. Lacroix, A. Luyckx, N. Pallikarakis, F. Pirnay, G. Krzentowski, and P. Lefebvre. 1981. Glucose oxidation in relation to the size of the oral glucose loading dose. Metab. Clin. Exp. 30:1143-1149.

18. Greenfield, A., R. Whitney, and J. Mowbray. 1963. Methods for the investigation of peripheral blood flow. Br. Med. Bull. 19:101109.

19. DuBois, E. 1924. Carbohydrate, fat, and protein. Basal Metabolism in Health and Disease. Lea and Febiger, Philadelphia. 14-23.

20. Lusk, G. 1924. Animal calorimetry: analysis of the oxidation of mixtures of carbohydrate and fat. J. Biol. Chem. 59:41-42.

21. Frayn, K. 1983. Calculation of substrate oxidation rates in vivo from gaseous exchange. J. Appl. Physiol. Respir. Environ. Exercise Physiol. 55:628-634.

22. Karl, I., A. Pagliaria, and D. Kipnis. 1972. A microfluorometric enzymatic assay for determination of alanine and pyruvate in plasma and tissue. J. Lab. Clin. Med. 80:434-441.

23. Lowry, O.; J. Passonneau, F. Hesselberger, and D. Schulz. 1964. Effect of ischemia on known substrates and cofactors of the glycolytic pathway in brain. J. Biol. Chem. 239:18-30.

24. Herbert, V., L. Lau, C. Gottlieb, and S. Bleicher. 1965. Coated charcoal immunoassay of insulin. J. Clin. Endocrinol. Metab. 25:1375-1384

25. Kreisberg, R., A. Siegal, and W. Owen. 1972. Alanine and gluconeogenesis in man: effect of ethanol. J. Clin. Endocrinol. Metab. 34:876-883.
26. Bloom, B. 1967. The simultaneous determination of [C14] and [H3] in the terminal groups of glucose. Anal. Biochem. 3:85-87.

27. Reichert, G., F. Mory, N. Hochella, A. Patterson, and S. Weinhouse. 1963. Quantitative estimation of the Cori cycle in humans. $J$. Biol. Chem. 238:485-501.

28. Ferrannini, E., O. Bjorkman, G. Reichard, A. Pilo, M. Olsson, J. Wahren, and R. DeFronzo. 1985. The disposal of an oral glucose load in healthy subjects: a quantitative study. Diabetes. 34:580-588.

29. Firth, R., P. Bell, H. Marsh, I. Hansen, and R. Rizza. 1986. Postprandial hyperglycemia in patients with noninsulin-dependent diabetes mellitus: roles of hepatic and extrahepatic tissues. J. Clin. Invest. 77:1525-1532.

30. Hetenyi, G., and K. Norwich. 1974. Validity of rates of production and utilization of metabolites as determined by tracer methods in intact animals. Fed. Proc. 33:1841-1864.

31. Chiasson, J., J. Liljenquist, W. Lacy, A. Jennings, and A. Cherrington. 1977. Gluconeogenesis: methodological approaches in vivo. Fed. Proc. 36:229-235.

32. Radziuk, J., T. McDonald, D. Rubenstein, and J. Dupre. 1978. Initial splanchnic extraction of ingested glucose in normal man. Metab. Clin. Exp. 27:657-669.

33. Cook, G. 1977. Rates and mechanisms of glucose, galactose and xylose absorption in man in vivo. Scand. J. Gastroenterol. 12:733-737.

34. Dillion, R. 1965. Importance of hematocrit in interpretation of blood sugar. Diabetes. 14:672-678.

35. Felig, P. 1973. The glucose-alanine cycle. Metab. Clin. Exp. 22:179-207.

36. Cooper, K., O. Edholm, and R. Mottram. 1955. The blood flow in skin and muscle of the human forearm. J. Physiol. 128:258-267.

37. Heymsfield, S., C. McManus, V. Stevens, and J. Smith. 1982. Muscle mass: reliable indicator of protein-energy malnutrition severity and outcome. Am. J. Clin. Nutr. 35:1192-1199.

38. Lyngsoe, J., J. Clausen, J. Trap-Jensen, L. Sestoft, O. Schaffabtosky, J. Holst, S. Nielsen, and J. Rehfeld. 1978. Exchange of metabolites in the leg of exercising juvenile diabetic subjects. Clin. Sci. Mol. Med. 55:73-80.

39. Jackson, R., P. Blix, J. Matthews, L. Morgan, A. Rubenstein, and J. Nabarro. 1983. Comparison of peripheral glucose uptake after oral glucose loading and a mixed meal. Metab. Clin. Exp. 32:706-710.

40. Eisenberg, S., and H. Seltzer. 1962. The cerebral metabolic effects of acutely induced hypoglycemia in normal subjects. Metab. Clin. Exp. 11:1162-1168.

41. Della Porta, P., A. Maiolo, V. Negri, and E. Rossella. 1964. Cerebral blood flow and metabolism in therapeutic insulin coma. Metab. Clin. Exp. 13:131-140.

42. Gottstein, U., A. Bernsmeier, and I. Sedlmeyer. 1963. Der Kohlenhydratstoffwechsel des menschlichen Gehirns. I. Untersuchungen mit substratspezifischen enzymatischen Methoden bei normaler Hirndurchblutung. Klin. Wochenschr. 41:943-948.

43. Bergman, R., J. Bier, and P. Hourigan. 1982. Intraportal glucose infusion matched to oral glucose absorption. Lack of evidence for "gut factor" involvement in hepatic glucose storage. Diabetes. 31:2735.

44. Aburmrad, N., A. Cherrington, P. Williams, W. Lacy, and D. Rabin. 1982. Absorption and disposition of a glucose load in the conscious dog. Am. J. Physiol. 242:E398-E406.

45. Radziuk, J., C. Nohr, S. Pye, and R. Mustard. 1985. The metabolic fate of a $100 \mathrm{~g}$ oral load in man. In Diabetes. M. Sernon-Rios and P. Lefebrve, editors. Exerpta Medica, New York. 328-331.

46. Consoli, A., F. Kennedy, J. Miles, and J. Gerich. 1987. Determination of Krebs cycle metabolic carbon exchange in vivo and its use to estimate the individual contributions. J. Clin. Invest. 80:1303-1310.

47. Radziuk, J. 1982. Sources of carbon in hepatic glycogen synthesis during absorption of an oral glucose load in humans. Fed. Proc. 41:110-116.

48. Felig, P., J. Wahren, and R. Hendler. 1975. Influence of oral glucose ingestion on splanchnic glucose and gluconeogenic substrate metabolism in man. Diabetes. 24:468-475. 
49. Waldhausl, W., S. Gasic, P. Bratusch-Marrain, and P. Nowotny. 1983. The 75-g oral glucose tolerance test: effect on splanchnic metabolism of substrates and pancreatic hormone release in healthy man. Diabetologia. 25:489-495.

50. Wahren, J., and P. Felig. 1975. Renal substrate exchange in human diabetes mellitus. Diabetes. 24:730-734.

51. Bjorkman, O., P. Felig, and J. Wahren. 1980. The contrasting responses of splanchnic and renal glucose output to gluconeogenesis substrates and to hypoglycagonemia in $60-\mathrm{h}$ fasted humans. Diabetes. 29:610-616.

52. Foss, M., F. Vlachokosta, L. Cunningham, and T. Aoki. 1982. Restoration of glucose homeostasis in insulin-dependent diabetic subjects: an inducible process. Diabetes. 31:46-52.

53. Bjorntorp, P., and L. Sjostrom. 1978. Carbohydrate storage in man: speculations and some quantitative considerations. Metab. Clin. Exp. 27(Suppl. 2):1853-1865.
54. Felber, J.-P., G. Magnenat, M. Casthelaz, C. Geser, R. MullerHess, N. de Kalbermatten, J. Ebiner, B. Curchod, P. Pittett, and E. Jequier. 1977. Carbohydrate and lipid oxidation in normal and diabetic subjects. Diabetes. 26:693-699.

55. Boden, G., T. Ray, R. Smith, and O. Owen. 1983. Carbohydrate oxidation and storage in obese noninsulin-dependent diabetic patients: effects of improving glycemic control. Diabetes. 32:982-987.

56. Sato, S., M. Tateyama, C. Sasamori, S. Kobayashi, Y. Chiba, and Y. Takeda. 1963. On the intermediate metabolism of carbohydrates in the brain of healthy persons. Tohoku J. Exp. Med. 81:215221.

57. Cohen, P., S. Alexander, F. Smith, M. Reivich, and H. Wollman. 1967. Effects of hypoxia and normocarbia on cerebral blood glow and metabolism in conscious man. J. Appl. Physiol. 23:183-189.

58. Wisneski, J., E. Gertz, R. Neese, L. Gruenke, D. Morris, and J. Craig. 1985. Metabolic fate of extracted glucose in human myocardium. J. Clin. Invest. 76:1819-1827. 